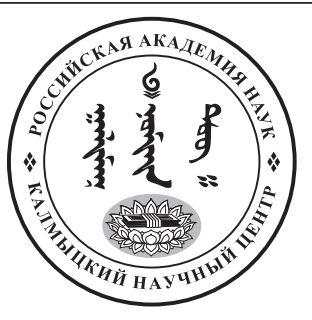

Published in the Russian Federation

Oriental Studies (Previous Name: Bulletin of the Kalmyk Institute

for Humanities of the Russian Academy of Sciences)

Has been issued as a journal since 2008

ISSN: 2619-0990; E-ISSN: 2619-1008

Vol. 13, Is. 5, pp. 1310-1330, 2020

DOI: $10.22162 / 2619-0990-2020-51-5-1310-1330$

Journal homepage: https://kigiran.elpub.ru

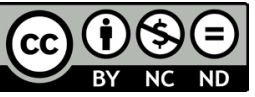

УДК 902

DOI: 10.22162/2619-0990-2020-51-5-1310-1330

\title{
Социальные различия у носителей пазырыкской культуры
}

\author{
Мария Александровна Очир-Горяева ${ }^{1}$
}

${ }^{1}$ Калмыцкий научный центр РАН (д. 8, ул. им. И. К. Илишкина, 358000 Элиста, Российская Федерация)

доктор исторических наук, ведущий научный сотрудник

iD 0000-0002-0210-7595. E-mail: mariaochir@gmail.com

\author{
(C) КалмНЦ РАН, 2020 \\ (C) Очир-Горяева М. А., 2020
}

Аннотация. Введение. Исследователей пазырыкской культуры интересовал вопрос о социальной структуре общества ее носителей. Традиционно ученые выделяли три социальные группы среди пазырыкцев на основе сравнения высоты и диаметра курганов, глубины и площади могильных ям, количества сопровождающих коней, а также количества и качества погребального инвентаря. Цель статьи - анализ социальных различий населения пазырыкской культуры по данным погребального обряда. Результаты. Традиционно для выявления социальных слоев исследователи брали за основу размерные и количественные данные погребальных сооружений. Автор статьи обратила внимание на позу погребенных и степень скорченности их ног. В рядовых погребениях из малых курганов все умершие положены на правом боку, головой на восток, лицом на север, но с выражено подогнутыми ногами, то есть они лежат в скорченном положении. В элитных княжеских погребениях из больших пазырыкских курганов умершие были положены так же, как и в рядовых: на боку, головой на восток, лицом на север, но только вытянуто во весь рост, со слегка подогнутыми ногами. Bblвoдbl. Если погребенных из элитных погребений представить со слегка «преклоненными коленями», как бы делающими книксен, то погребенных из рядовых курганов можно представить низко присевшими или упавшими ниц. Ранее этот признак не рассматривался как важный, так как вытянутое положение совпадало с расположением умерших в колоде, выдолбленной из цельного ствола дерева. Проведенное сравнение ширины колод и роста мумий подвело автора к убеждению, что вытянутая поза была предписана обрядом, она не была вынужденной из-за формы и размеров колоды. Опираясь на предыдущие исследования, автор рассматривает и интерпретирует выявленный ею аспект в общем контексте погребального обряда и представлений о мире мертвых носителей пазырыкской культуры.

Ключевые слова: Горный Алтай, пазырыкская культура, скифская эпоха, мумии, элитные погребения, колода-саркофаг, курганы, социальные слои

Благодарность. Исследование проведено в рамках государственной субсидии - проект «Комплексное исследование процессов общественно-политического и культурного разви- 
тия народов Юга России» (номер госрегистрации: АААА-А19-119011490038-5), а также при финансовой поддержке гранта в форме субсидии из федерального бюджета, выделяемой для государственной поддержки научных исследований, проводимых под руководством ведущего ученого (проект «От палеогенетики до культурной антропологии: комплексное интердисциплинарное исследование традиций народов трансграничных регионов: миграции, межкультурное взаимодействие и картина мира»).

Для цитирования: Очир-Горяева М. А. Социальные различия у носителей пазырыкской культуры // Oriental Studies. 2020. T. 13. № 5. C. 1310-1330. DOI: 10.22162/2619-0990-2020-51-5$1310-1330$

UDC 902

DOI: $10.22162 / 2619-0990-2020-51-5-1310-1330$

\title{
Burials of Pazyryk Culture: Social Differentiations
}

\author{
Maria A. Ochir-Goryaeva \\ ${ }^{1}$ Kalmyk Scientific Center of the RAS (8, Ilishkin St., Elista 358000, Russian Federation) \\ Dr. Sc. (History), Leading Research Associate \\ iD 0000-0002-0210-7595.E-mail: mariaochir@gmail.com
}

\author{
(C) KalmSC RAS, 2020 \\ (C) Ochir-Goryaeva M. A., 2020
}

\begin{abstract}
Introduction. Specialists dealing with the Pazyryk culture keep posing questions about its social structure. Traditionally, scholars - with due account of outer parameters of kurgans, depths and areas of graves, numbers of buried horses, quantities and qualities of burial utensils have tended to identify three groups within the Pazyryk. Goals. The paper aims to analyze Pazyryk burial rites for social differences within the culture. Results. When it comes to social classifications, researchers usually form respective hypotheses on the bases of dimensional and quantitative properties of examined burial facilities. Still, the paper specifically focuses on positions of the buried and on how crouched their legs are. In common burials from minor kurgans, all bodies are placed lying on their right side with heads to the east (faces to the north), and with legs strongly doubled up, i.e. in crouched positions. In elite princely burials from large Pazyryk kurgans, bodies lie in similar positions - on the left side with heads to the east — but are stretched to their full heights with slightly bent legs. Conclusions. So, the buried elites can be imagined doing a 'curtsy' with legs 'slightly bent in the knees', while the commoners would be seen paying deep knee bends or even prostrating themselves. This feature was never viewed as essential since the stretched position matched the shape of coffins carved from single tree trunks. The work compares widths of coffins and heights of mummies to conclude that the stretched position was determined by rites rather than by shapes or sizes of the coffins. Proceeding from previous studies, the paper examines and interprets the discovered aspect in the context of Pazyryk burial rites and related ideas about the world of the dead.
\end{abstract}

Keywords: Gorno-Altai Republic, Pazyryk culture, Scythian era, mummies, elite burials, tree-trunk coffins, kurgans, social strata

Acknowledgements. The reported study was funded by government subsidy — project name 'SocioPolitical and Cultural Development of South Russia's Peoples: Comprehensive Studies of Respective Processes' (state reg. no. AAAA-A19-119011490038-5) — and by government grant in the form of federal budget subsidy aimed to support scientific research directed by the Leading Scientist — project name 'From Paleogenetics to Cultural Anthropology: Comprehensive Interdisciplinary Research of Peoples and Traditions of Cross-Border Regions - Migrations, Cross-Cultural Interactions and Worldviews'.

For citation: Ochir-Goryaeva M. A. Burials of Pazyryk Culture: Social Differentiations. Oriental Studies. 2020. Vol. 13(5): 1310-1330. (In Russ.). DOI: 10.22162/2619-0990-2020-51-5-1310-1330 


\section{Введение}

C первых раскопок курганов пазырыкской культуры предпринимались попытки реконструировать социальную структуру общества ее носителей. Основными критериями для выделения социальных слоев для всех исследователей были размерные данные: высота и диаметр курганов, глубина и площадь могильных ям, количество сопровождающих коней, а также количество и качество погребального инвентаря. Перечисленные показатели являются объективными и действительно наиболее показательными параметрами для выделения различий в социальном статусе погребенных. С небольшими непринципиальными деталями большинство исследователей делило пазырыкское общество на три социальные группы: 1) погребения рядовых номадов, 2) курганы знати (племенной и/ или родовой), 3) погребения вождей племен [Грязнов 1950: 67-72; Руденко 1960: 51-63, 224-248; Руденко 1953: 253-271; Суразаков 1988: 72-87]. В отношении больших пазырыкских курганов термин «царские» был применен впервые А. Д. Грачом [Грач 1980: 64]. Остальные исследователи до и после него придерживались термина «погребения вождей».

Из последних работ обращает на себя внимание монография А. А. Тишкина и П. К. Дашковского «Социальная структура и система мировоззрений населения Алтая скифской эпохи» [Тишкин, Дашковский 2003]. Авторы привлекли к анализу весь комплекс источников: размеры насыпей, могильных ям, ориентацию погребенных, наличие сопровождающих захоронений коней, наличие и расположение погребального инвентаря и т. д. по данным 569 погребений пазырыкской культуры из 135 могильников. В результате анализа была выявлена 21 социально-типологическая модель по признакам пола и возраста, которые в значительной степени перекрываются ввиду коллективного характера значительной части погребений, составляющих $39 \%$ от общего количества, т. е. 234 погребения [Тишкин, Дашковский 2003: 174]. В силу высокой степени детализации признаков и возрастных групп возник статистический шум, который не позволил авторам получить новые данные по предмету исследования [Тишкин, Дашковский 2003: 231].

Задача данной статьи обратить внимание на другой аспект - различия, которые наблюдаются внутри групп, выделенных по размерам погребальных сооружений. На мой взгляд, эти особенности дополняют полученные представления о социальных различиях в среде пазырыкцев и выявляют новые информационные возможности археологических источников.

Материалы и методы. Погребальный обряд пазырыкской культуры отличается высокой степенью стандартизации. Для пазырыкской культуры характерны каменные курганы с одним погребением, расположенные на местности в виде вытянутых по линии Север-Юг цепочек. Это служит хорошим опознавательным признаком пазырыкских курганов, отличающих их от курганов других культур. Как оказалось, расположение пазырыкских курганов в строгом меридиональном направлении является прямым отражением ориентации пазырыкского населения на местности - лицом на восток [Очир-Горяева 2012б: 441-446]. При таком расположении восточная сторона воспринималась как передняя, положительная, а западная - как задняя, там располагалась страна мертвых. Поэтому поминальные кольца находились на западе от курганной цепочки. А сами курганные цепочки строились по принципу правой и левой руки. При расположении лицом на восток важным и правильным было южное направление, потому что оно было по правую руку, а северное направление было менее почетным, так как располагалось по левую руку [Очир-Горяева 2018: 57-87]. Соответственно, курганы, в которых погребали более почетных, старших пазырыкцев, располагались в южной части цепочки. Например, в кургане 1 Туэкта был погребен мужчина, а в кургане 2, расположенном севернее, была погребена женщина [Руденко 1960: 96-109].

Этот же принцип соблюдался внутри могильной ямы. Погребенные в пазырыкских курганах всегда положены вдоль южной 
стены деревянного сруба на полу-настиле, в деревянной колоде или на так называемых ложах-столах, похожих на кровать. В случаях коллективных погребений взрослый лежит всегда на юге, а севернее перед ним положен ребенок. Тот же принцип соблюдался при погребении мужчины и женщины. Женщина всегда находится севернее мужчины. В случае однополых парных погребений, по всей видимости, соблюдался принцип старшинства. Так в кургане 6 могильника Уландрык-II были погребены две женщины с сопроводительными захоронениями трех коней. Южный скелет принадлежал женщине старческого возраста: об этом свидетельствовали «атрофированная нижняя челюсть» и выпавшие зубы, аккуратно сложенные в мешочек, подвешенный к поясу умершей. Северный скелет принадлежал рослой молодой женщине [Кубарев 1987: 172]. Кони в пазырыкских погребениях всегда расположены с северной стороны за стенкой сруба на приступке или на дне ямы. В результате наблюдается такая картина: пазырыкцы располагали захороненных по мере убывания важности с юга на север. На юге располагался мужчина или главное погребенное лицо, далее были положены женщины и дети, а еще дальше, за стенкой сруба, были положены сопровождающие захоронения коней.

Как правило, перед лицом погребенных вдоль северной стены или в северо-восточном углу сруба были расставлены предметы, рассматриваемые обычно как предметы хозяйственного инвентаря: деревянный столик на ножках с крестцом овцы или лошади и железным ножом, а также строго индивидуальный набор из трех сосудов: глиняного кувшина, деревянного и рогового сосудиков или их заменителей из глины или бересты (наличие последних двух зависело от сохранности материала) ${ }^{1}$. Если погребе-

\footnotetext{
${ }^{1}$ Например, роговые сосуды в форме кувшинов с округлым дном и широким горлом-раструбом сохранились полностью всего в нескольких погребениях. Во многих других были найдены только фрагменты роговых сосудов. Найденные в трех больших Пазырыкских курганах части роговых сосудов были приняты С. И. Руденко за барабаны [Руденко 1953: 52]. В кургане 2 могильника Уландрык-1 роговой сосуд был заменен берестяным, полностью повторяющим форму рогового [Кубарев 1987: табл. VI, 5].
}

ние было коллективным, то алтарный столик и сосуды были поставлены для каждого отдельно, включая детей. Наборы из алтарного столика и сосудов были поставлены как в могилах рядовых пазырыкцев, так и в больших княжеских курганах. Со времени раскопок кургана Шибе в 1927 г. было установлено, что умершие в больших княжеских погребениях были мумифицированы [Руденко 1953: 327]. С открытием мумии в кургане 3 могильника Верхний Кальджин-2 было установлено, что и в простых рядовых могилах умершие были также бальзамированы [Феномен... 2000: 86-111]. Согласно последним исследованиям, устойчивый набор сосудов выполнял роль канопов, т. е. в них хранились внутренние органы мумий, алтарный столик с крестцом был подношением высшим силам. Более того, судя по расположению шерстяных веревочек

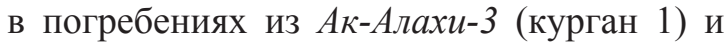
Верхний Кальджин (курган 3), они были привязаны одним концом к мизинцу одной руки, протянуты вокруг умершего и набора сосудов и другим концом закреплены на мизинце другой руки. Таким образом, на наш взгляд, была подчеркнута неразрывная связь мумии с емкостями и их содержимым [Очир-Горяева 2015: 228-236].

Все остальные вещи в могилах, обычно считающиеся предметами погребального инвентаря, не являются ими, а относятся к деталям головного убора, украшениям и предметам вооружения, носившимся на поясе погребенного, т. е. к предметам костюма или, в более общем смысле, к убранству умершего. До сих пор это обстоятельство как-то не осознавалось исследователями, и, соответственно, не обсуждалось в литературе. Только в единичных погребениях были зафиксированы музыкальные инструменты: арфы, шесты от треног и сосудики для воскурения. Д. Г. Савинов в свое время также обратил внимание на стандартность «утилитарного набора» предметов в пазырыкских курганах, независимо от социального статуса. Он предположил, что такие предметы, как курильница для воскурения конопли и арфа, не входящие в этот набор, использовались посетителями курганов во время ритуальных действий, проводившихся в течение длительного времени. Поэтому он предлагал рассматривать пазырыкские срубы-камеры как своего рода часовни. 
В качестве аргумента Д. Г. Савинов приводил убедительный факт, что высота пазырыкских деревянных срубов в княжеских курганах, позволяющая человеку стоять в полный рост, была необходима во время проведения ритуалов в деревянном срубе-часовне [Савинов 1995; Савинов 1996; Савинов 1997]. Нами же замечено, что арфа и набор для воскурения во всех случаях располагались в ногах погребенного у западной стены могилы, в то время как набор сосудов-каноп и алтарный столик с подношением всегда располагаются перед лицом погребенного, впереди него. Полагаем, этим подчеркивалось различное назначение предметов. Высота внутренних камер-срубов пазырыкской знати варьирует от 1,5-1,7 м, что действительно позволяет передвигаться внутри сруба, если не в полный рост, то пригнувшись. Таким образом, в погребениях пазырыкской культуры погребальный инвентарь в классическом понимании: заупокойная пища и предметы обихода и роскоши для использования умершим на том свете, как, например, в скифских могилах Северного Причерноморья, полностью отсутствует. При таком понимании пазырыкцы отправлялись в лучший мир, надев на себя и на сопровождающего коня (коней) все лучшее ${ }^{2}$, «прихватив» сосуды со своими внутренними органами, сумочки с ногтями и волосами, т. е. собрав в одну целостность своего тела и имея перед собой алтарный столик с подношением богам в виде крестцовой части овцы или лошади как символа плодородия ${ }^{3}$, как залога предстоящего благополучного возрождения умершего.

${ }^{2}$ В большинстве погребений этот принцип соблюдался в наиболее экономной форме. В пазырыкской культуре, как в никакой другой, широко использовалась бутафория - деревянные заменители реальных предметов, а также специально изготовленные миниатюрные копии металлического оружия.

3 По представлениям тюрко-монгольских народов крестец овцы или лошади усиливает детородную функцию. У калмыков родители при первом посещении дочери после свадьбы обязательно везут целиком сваренный крестец овцы. Для угощения этим мясом новоиспеченная невестка должна пригласить родственниц ее мужа: только замужних женщин и только детородного возраста. Если они отсутствовали или их было мало, то приглашали замужних соседок детородного возраста.
Одним из наиболее общих признаков является расположение погребенных на правом боку, головой на восток, лицом на север. Так расположены погребенные и в курганах вождей в больших княжеских пазырыкских курганах, и в мелких курганах рядовых общинников с насыпями, близкими по размерам к могильным холмикам. Это традиционная для пазырыкской культуры поза погребенных.

Естественно, как во всех других регионах и культурах, среди памятников пазырыкской культуры встречаются погребения, в которых умершие были положены несколько иначе, чем принято было в большинстве погребений. Например, имеются погребения, в которых умершие положены не в деревянных срубах или рамах, как большинство, а в каменных ящиках. Погребения с нетрадиционными чертами, однако, не образуют статистически выделяемые, локально ограниченные группы. Они встречаются единично и расположены в одной цепочке курганов с обычными погребениями, что является твердым показателем того, что в этих могилах были похоронены кровные родственники [Кубарев, Шульга 2007: 36-46].

Ориентация головой погребенных пазырыкской культуры изменяется только в тех случаях, когда цепочка курганов отклоняется от своей меридиональной оси в силу особенностей рельефа. Кроме того, имеются погребения, в которых умершие были положены головой в противоположную сторону, т. е. на запад, соответственно, на левом боку, лицом на север. Однако и это не является принципиальным различием, так как их общая ориентация, тем не менее, остается широтной. Порядок расположения людей и сопровождающих коней в этих могилах остается таким же, как в большинстве могил, лицом погребенные обращены также на север. Как показали исследования автора данной работы по ориентации погребальных сооружений степной зоны Евразии скифской эпохи, принципиальное этнокультурное разделение идет по признаку широтной или меридиональной ориентации погребального сооружения в целом. Внутри широтной или меридиональной ориентации погребального сооружения расположение головы погребенного в противоположном от традиционного направления не играет решающей роли [Очир-Горяева 2008; 
Очир-Горяева 2012а; Очир-Горяева 2014а]. В традиционных культурах подобные вариации в обрядах обычно связаны с обстоятельствами смерти. Например, так захоранивали самоубийц или убитых молнией ${ }^{4}$.

Стандартность позы погребенных в пазырыкских курганах, на первый взгляд, не оставляет возможности для выявления социальных различий. Наблюдается одна деталь - степень скорченности ног погребенных. В рядовых погребениях из малых курганов все умершие положены на правом боку, головой на восток, лицом на север, но с выражено подогнутыми ногами, т. е. лежат в скорченном положении (рис. $1 \mathrm{a}, 1 \mathrm{~b}, 1 \mathrm{c}$, 1d). Размеры деревянных срубов и каменных ящиков в рядовых погребениях были рассчитаны на скорченное положение, только над головой зачастую было оставлено место для высокого головного убора. Экономия дерева для срубов не может считаться причиной, так как на Алтае строительный лес имеется в изобилии даже в настоящее время. Значит, таковы были предписания обряда, традиция.

В элитных княжеских погребениях из больших пазырыкских курганов умершие были положены так же, как и в рядовых: на боку, головой на восток, лицом на север, но только вытянуто во весь рост, со слегка подогнутыми ногами (рис. 2a, 2b). Если погребенных из элитных погребений представить со слегка «преклоненными коленями», как бы делающими книксен, то погребенных из рядовых курганов можно представить низко присевшими или упавшими ниц. Это представление усиливает положение рук погребенных. У погребенных в скорченной позе руки зачастую положены перед собой, иногда даже как бы вытянуты перед собой, направлены к сосудам и столику. Возможно, это следствие связывающей их шерстяной веревочки. У погребенных же в вытянутой позе руки всегда опущены вниз. Получается, у «присевших» набор сосудов и столик с крестцом стоят перед ними, а у «слегка преклонивших колени» набор сосудов и крестец овцы оказались по уровню ниже (рис. 1a, 1b, 1c, 1b; 2a, 2b).

${ }^{4}$ У калмыков самоубийц хоронят головой в противоположную сторону, так как они не закончили круг своей жизни. Убитые молнией считались отмеченными небом, их хоронили с особыми почестями, иногда — как духовных лиц.
Аналогичная ситуация прослеживается и по могилам скифов Северного Причерноморья. Скорченное положение слуг-скифов в царских курганах отражает, скорее всего, их низкий социальный статус. Аналогично тому, как при появлении царя придворные вельможи делали поклон стоя, а люди низкого, «подлого», происхождения должны были опуститься на колени. Этнографически зафиксированы похожие формы обыденных приветствий. По данным Н. Я. Бичурина, представители протомонгольского племени ухуани при взаимной встрече приседали друг перед другом [Бичурин 1851].

По данным Е. П. Бунятян, в малых скифских курганах встречаются могилы, специально выкопанные для расположения умершего в скорченном положении (длиной до 155 см). При этом некоторые из них были снабжены инвентарем в виде бус и наконечников стрел. На этом основании Е. П. Бунятян уверено относила их к могилам рядовых общинников, а не рабов [Бунятян 1985: $30,94]$.

В отношении пазырыкских погребений вопрос осложняется тем, что погребенные со слегка преклоненными коленями были положены в колоды, что могло послужить причиной расположения умерших вытянуто. Действительно, в больших курганах вождей или княжеских курганах умершие были похоронены в колодах из стволов мощных сибирских лиственниц или кедра. Все колоды были плотно закрыты крышками и забиты деревянными клиньями [Руденко 1960: табл. XXV].

Обсуждение. Первоначальная (insitu) поза погребенных в колодах была прослежена только в некоторых элитных погребениях: кургане 1 Башадар (мужчина в колоде), кургане 1 Туэкта (мужчина в колоде), кургане 11 Берель (мужчина и женщина в одной колоде), кургане 1 Ак-Алахе-1 (мужчина и юноша, каждый в своей колоде), кургане 1 Ак-Алахе-3 (женщина в колоде). Во всех перечисленных случаях умершие были обнаружены в позе на боку, вытянуто, со слегка подогнутыми ногами. Только в кургане 1 Башадар умерший находился вытянуто на спине.

Теперь необходимо прояснить вопрос: не была ли вытянутая поза погребенных следствием расположения умерших в колоде-саркофаге. На первый взгляд, причинно-следственная связь кажется очевидной. 


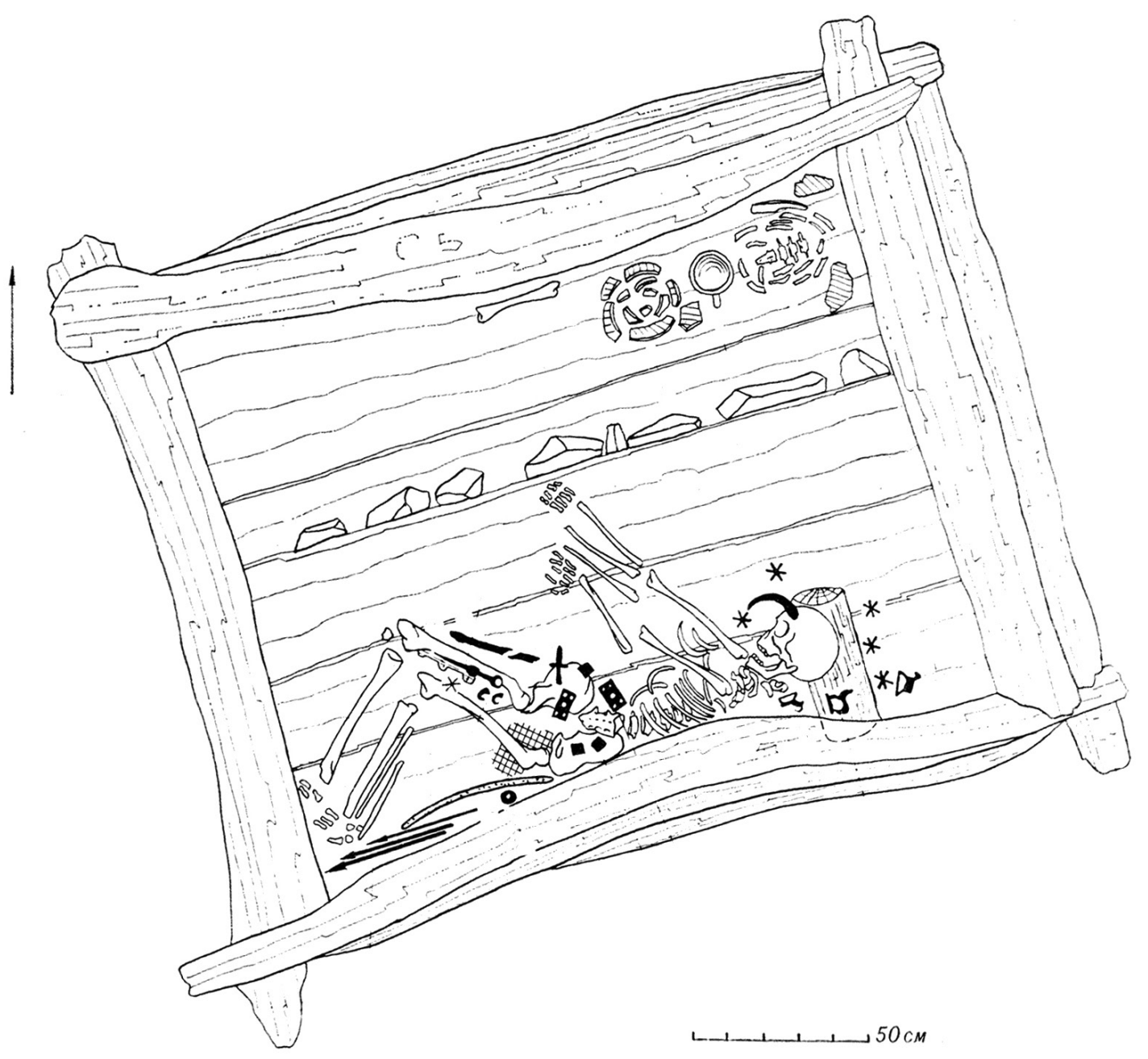

Puc. 1a. Расположение погребенного и предметов в рядовых погребениях пазырыкской культуры: Уландрык-IV, курган 1 [Кубарев 1987: 269, табл. LXVIII]

[Fig. 1a. Layout of remains and tools in burials of Pazyryk commoners: Ulandryk-IV, kurgan 1] 


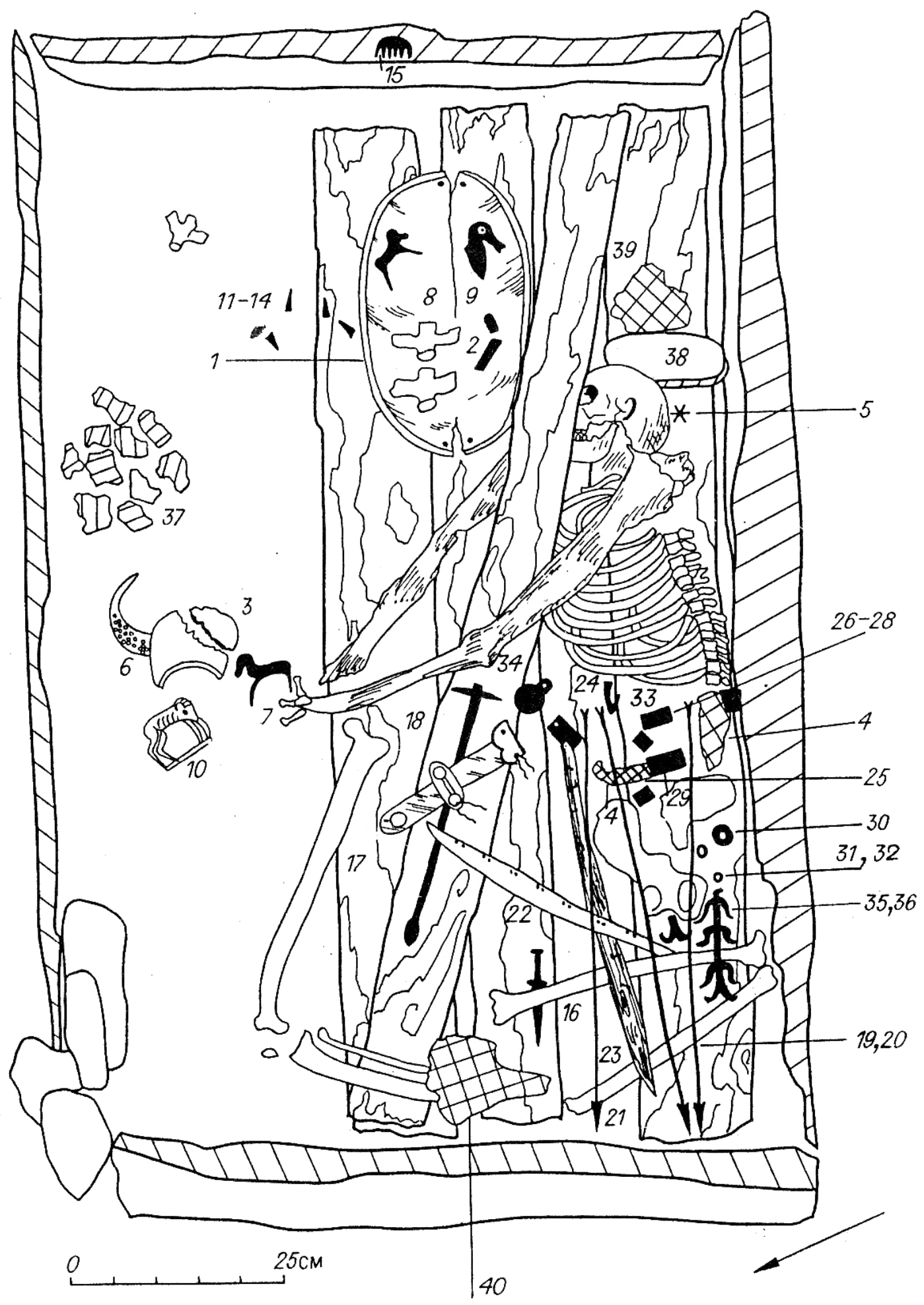

Puc. 1 b. Расположение погребенного и предметов в рядовых погребениях пазырыкской культуры: Барбугазы, курган 25 [Кубарев 1992: табл. XXIX]: 1-40 - погребальный инвентарь

[Fig. 1b. Layout of remains and tools in burials of Pazyryk commoners: Barbugazy, kurgan 25: 1-40burial inventory] 


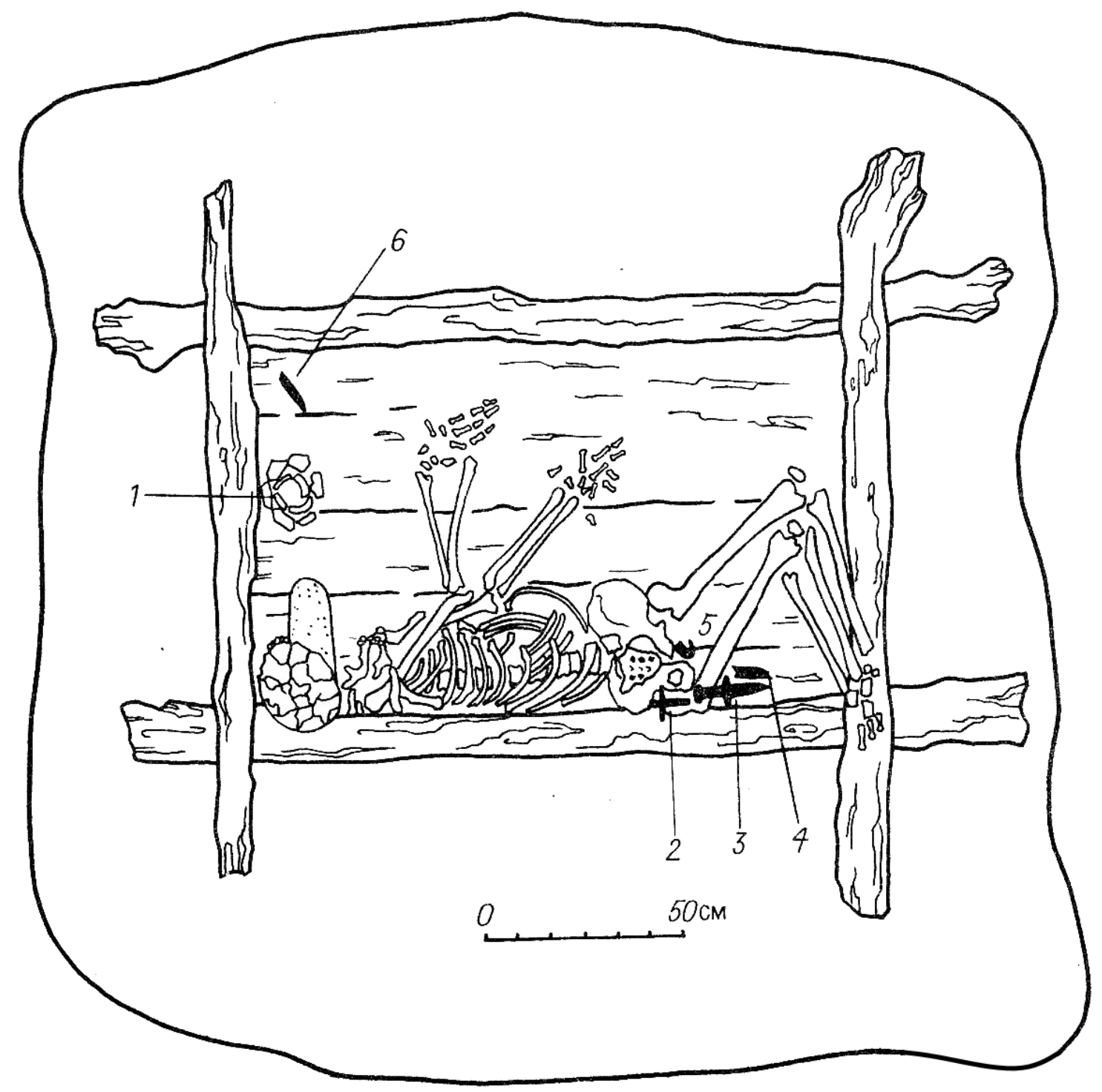

Puc. 1c. Расположение погребенного и предметов в рядовых погребениях пазырыкской культуры: Малталу-IV, курган 5 [Кубарев 1992: табл. XLIV]: 1-6 - погребальный инвентарь

[Fig. 1c. Layout of remains and tools in burials of Pazyryk commoners: Maltalu-IV, kurgan 5: 1-6 — burial inventory] 


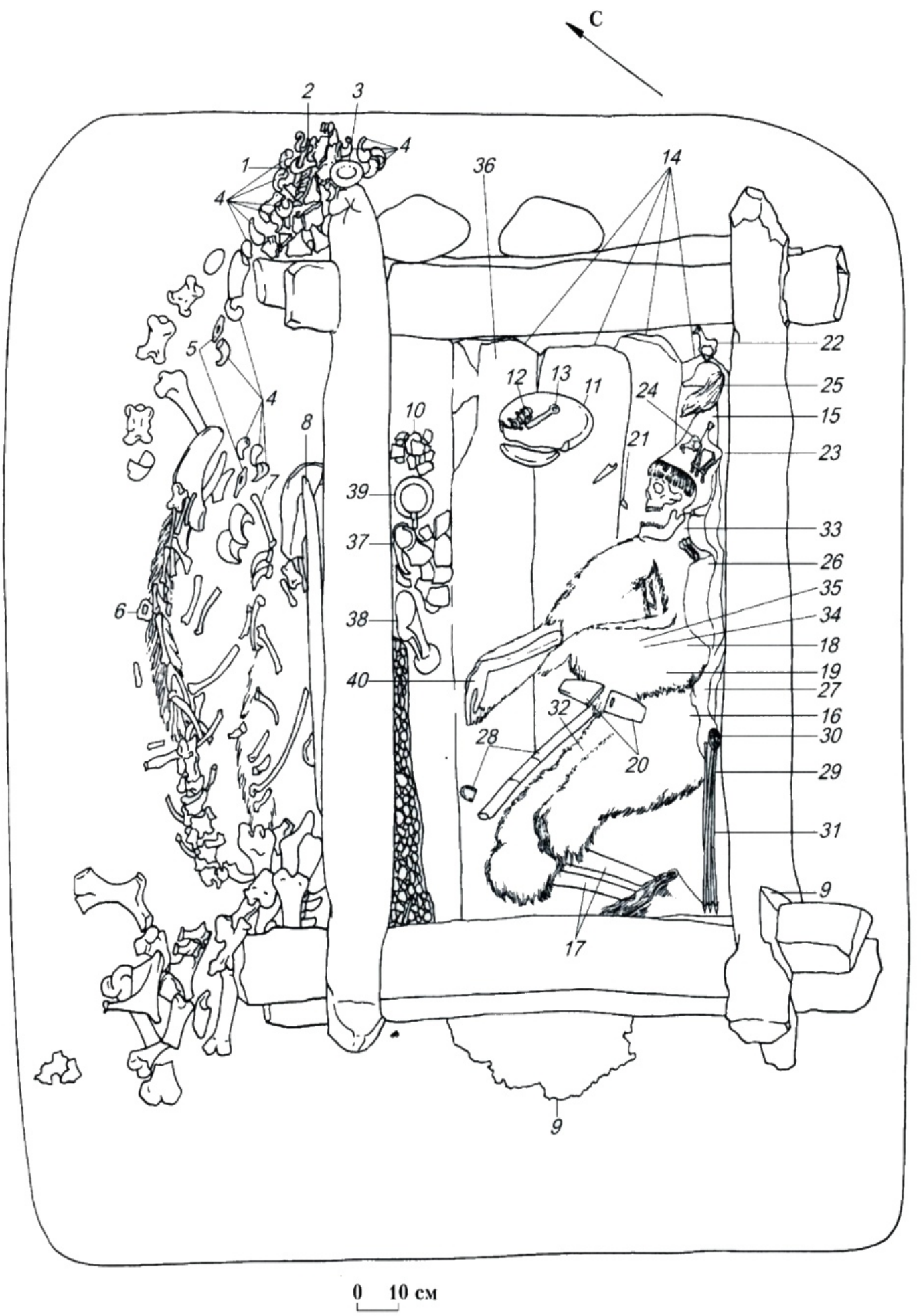

Puc. $1 d$. Расположение погребенного и предметов в рядовых погребениях пазырыкской культуры: Верхний Кальджин-II, курган 3 [Феномен... 2000: рис. 108]: 1-40 - погребальный инвентарь

[Fig. 1d. Layout of remains and tools in burials of Pazyryk commoners: Verkhny Kaldzhin-II, kurgan 3: $1-40$ - burial inventory] 
Но при внимательном рассмотрении выясняется, что причиной их вытянутого расположения были все же предписания обряда. Во-первых, при необходимости пазырыкцы могли выбрать для колоды лиственницы с более мощным стволом. Как известно, стволы сибирских лиственниц могут достигать в диаметре от 100 до 180 см при высоте до 30-40 м. Во-вторых, имеются несколько детских погребений с расположением умерших в колоде скорченно [Кубарев 1987: 21-22; Кубарев 1991: 31; Кубарев 1992: 20]. Все колоды имели размеры, соответствующие росту детей до полутора метра в длину, только в кургане 1 Барбугазы-I колода для подростка имела размеры 200х50x40 cм [Кубарев 1992: табл. II].

Чтобы быть абсолютно уверенными, рассмотрим размеры колод-саркофагов, чтобы установить: возможно ли было в них подогнуть ноги умерших так, чтобы придать им позу скорченности (см. табл. 1). В таблице 1 собраны вместе все данные по размерам колод-саркофагов из элитных погребений. Указанная авторами раскопок ширина колод дана по внешнему краю. С. И. Руденко специально оговаривал то, что толщина боковых стенок колод составляет 3-4 см, торцовых стенок - 25-30 см, дна - обычно 9-13 см [Руденко 1953: 27]. В таком случае внутренняя ширина пазырыкских колод варьирует в пределах 92-57 см. Для расположения в колоде с согнутыми ногами решающую роль играет длина самой длинной кости в человеческом скелете - бедренной. Она составляет $27 \%$ от роста человека. В таблице 2 приведены данные по росту мужчин из пазырыкских колод. Мужчины из элитных погребений отличались высо- ким ростом по сравнению с погребенными из рядовых могил, средний рост которых составлял 164 см [Руденко 1953: 60]. Максимальный рост был у мужчины из кургана 3 Пазырык - 181 см (длина бедренной кости 48,8 см) и минимальным оказался рост мужчины из кургана 2 Бамадар - 170 см (длина бедренной кости 45,9 см). Рост женщин был значительно меньше роста мужчин и варьировал между 161 и 144 см, поэтому они не брались в расчет. Сравнение приведенных данных по ширине колоды и длине берцовых костей показывает, что вытянутая поза погребенных не была следствием невозможности уложить в колоде по-другому. Особенно наглядно это видно на плане погребения юноши из Ак-Алахи-3 кургана 1. Клевец располагается в колоде в 20 см от колен погребенного и примерно настолько же от внутренней стены колоды (рис. 2б). При этом не стоит упускать из виду, что речь идет о мумиях, у которых были удалены не только мозг, глаза, все органы брюшной полости, но и надрезаны и удалены мышцы во всем теле вплоть до мышц ступней. Практически это были скелеты, обтянутые кожей. Кроме того, колода была округлой и поэтому высота их также предоставляла дополнительное пространство. Крышки колод были сделаны из другого ствола, поэтому они также увеличивали объем пространства внутренней части колоды. Но, как видим на примере с клевцом, необходимости в дополнительном пространстве не было. Об этом же свидетельствует тот факт, что колода Ак-ахалинской принцессы была выдолблена на глубину всего лишь 30 см и не доведена до середины колоды, где диаметр был максимальным.

Таблища 1. Пазырыкская культура. Элитные курганы. Размеры колоды

[Table 1. Pazyryk culture. Elite kurgans. Parameters of coffins]

\begin{tabular}{|l|l|c|c|c|}
\hline № & \multicolumn{1}{|c|}{$\begin{array}{c}\text { Курганная группа и номер } \\
\text { кургана }\end{array}$} & $\begin{array}{c}\text { Ширина колоды } \\
\text { (диаметр ствола } \\
\text { дерева), см }\end{array}$ & $\begin{array}{c}\text { Длина } \\
\text { колоды, см }\end{array}$ & $\begin{array}{c}\text { Высота колоды } \\
\text { (без крышки), см }\end{array}$ \\
\hline 1 & Пазырык, курган 1 & 80 & 370 & 65 \\
\hline 2 & Пазырык, курган 2 & $95-87$ & 420 & 72 \\
\hline 3 & Пазырык, курган 3 & - & 325 & - \\
\hline 4 & Пазырык, курган 4, колода 1 & 70 & 300 & 40 \\
\hline 5 & Пазырык, курган 4, колода 2 & 70 & 250 & 36 \\
\hline 6 & Пазырык, курган 5 & 70 & 500 & - \\
\hline 7 & Кутургунтас, курган 1 & 80 & 300 & - \\
\hline
\end{tabular}

${ }^{5}$ В таблице 1 использованы данные из: [Руденко 1953; Руденко 1960; Полосьмак 2001]. 


\begin{tabular}{|l|l|c|c|c|}
\hline 8 & Ак-Алаха-1, курган 1, колода 1 & 80 & 270 & - \\
\hline 9 & Ак-Алаха-1, курган 1, колода 2 & 80 & 260 & - \\
\hline 10 & Ак-Алаха-3, курган 1 & 79 & 273 & 68 \\
\hline 11 & Берель, курган 11 & $68-86$ & 273 & 62 \\
\hline 12 & Бамадар, курган 1 & $60-70$ & 240 & 56 \\
\hline 13 & Бамадар, курган 2, колода южная & 84 & 310 & \\
\hline
\end{tabular}

Таблица 2. Пазырыкская культура. Элитные курганы. Рост и возраст мужчин ${ }^{6}$

[Table 2. Pazyryk culture. Elite kurgans. Heights and ages of buried men]

\begin{tabular}{|l|l|c|c|}
\hline \multicolumn{1}{|c|}{ № } & \multicolumn{1}{|c|}{ Курган } & Рост, см & Возраст, год \\
\hline 1 & Пазырык, курган 2 & 176 & 60 \\
\hline 2 & Пазырык, курган 3 & 181 & - \\
\hline 3 & Пазырык, курган 4 & 174 & - \\
\hline 4 & Пазырык, курган 5 & $175-176$ & 55 \\
\hline 5 & Шибе & 178 & 60 \\
\hline 6 & Башадар, курган 1 & 175 & 23 \\
\hline 7 & Башадар, курган 2 & 170 & $60-65$ \\
\hline 8 & Туэкта, курган 1 & 178 & $40-45$ \\
\hline
\end{tabular}

В Большом Катандинском кургане оба погребенных были уложены вытянуто на ложах-столах, похожих на кровати с ножками, украшенными «медными обручами» [Гаврилова 1957: 256]. Столы были рассчитаны на расположение умерших вытянуто. Известны еще несколько погребений на столах, но только в скорченной позе (курганы 2 и 22 Юстыл, курган 3 Верхний Кальджин-2, курган 1 Ак-Алаха-5). Размеры их столов были рассчитаны соответственно на скорченное расположение. Погребение женщины в скорченном положении на деревянном ложе из кургана 1 Aк-Алаха-5 сопровождалось захоронением шести лошадей, т. е. его можно отнести к погребениям знати [Полосьмак 2001: 89]. То же самое касается погребения из кургана 3 группы Верхний Кальджин, где погребенный был положен в скорченном положении. Таким образом, не всем представителям знати позволено было привилегированное вытянутое положение в саркофаге или на ложе.

Также необходимо специально рассмотреть случаи расположения в колоде не одного, а двух человек. Учитывая размеры колод, оставляющие свободное пространство вокруг одной мумии, расположение в них двух мумий, по всей видимости, не вызывало особых проблем. При расположении мумий в одинаковой позе, как в кургане 11

${ }^{6}$ В таблице 2 использованы данные: [Руденко 1953: 63].
Берель, срабатывал принцип ложек, сложенных в ящике буфета. Именно в такой позе расположены погребенные в рядовых погребениях. Этот факт легко устанавливается, так как голова «младшего» или северного погребенного, как правило, находится несколько ниже по уровню головы «старшего» или южного погребенного.

Во всех больших Пазырыкских курганах, кроме кургана 4, было установлено по одной колоде, в которой были найдены мумии мужчины и женщины, что понимается как супружеские погребения. При раскопках первого кургана не было уделено должного внимания останкам погребенных, разрушенных грабителями [Грязнов 1950]. Но имеются косвенные данные о том, что в камере были найдены «шесть [войлочных и травяных] колец-подставок под сосуды» [Руденко 1953: 363]. Согласно данным из последующих раскопок, для каждого умершего в больших курганах были поставлены три сосуда: керамический, деревянный и роговой. В ряде курганов прослежено, что сосуды эти ставились на подставки в виде колец. Три такие войлочные подставки под сосуды были сшиты друг с другом в кургане 3 могильника Верхний Кальджин-2 [Полосьмак 2001: рис. 132] или же пришиты к войлочному ковру, постеленному на полу камеры [Руденко 1953: рис. 43]. Исходя из количества подставок-колец в первом Пазырыкском кургане были похоронены два человека. 


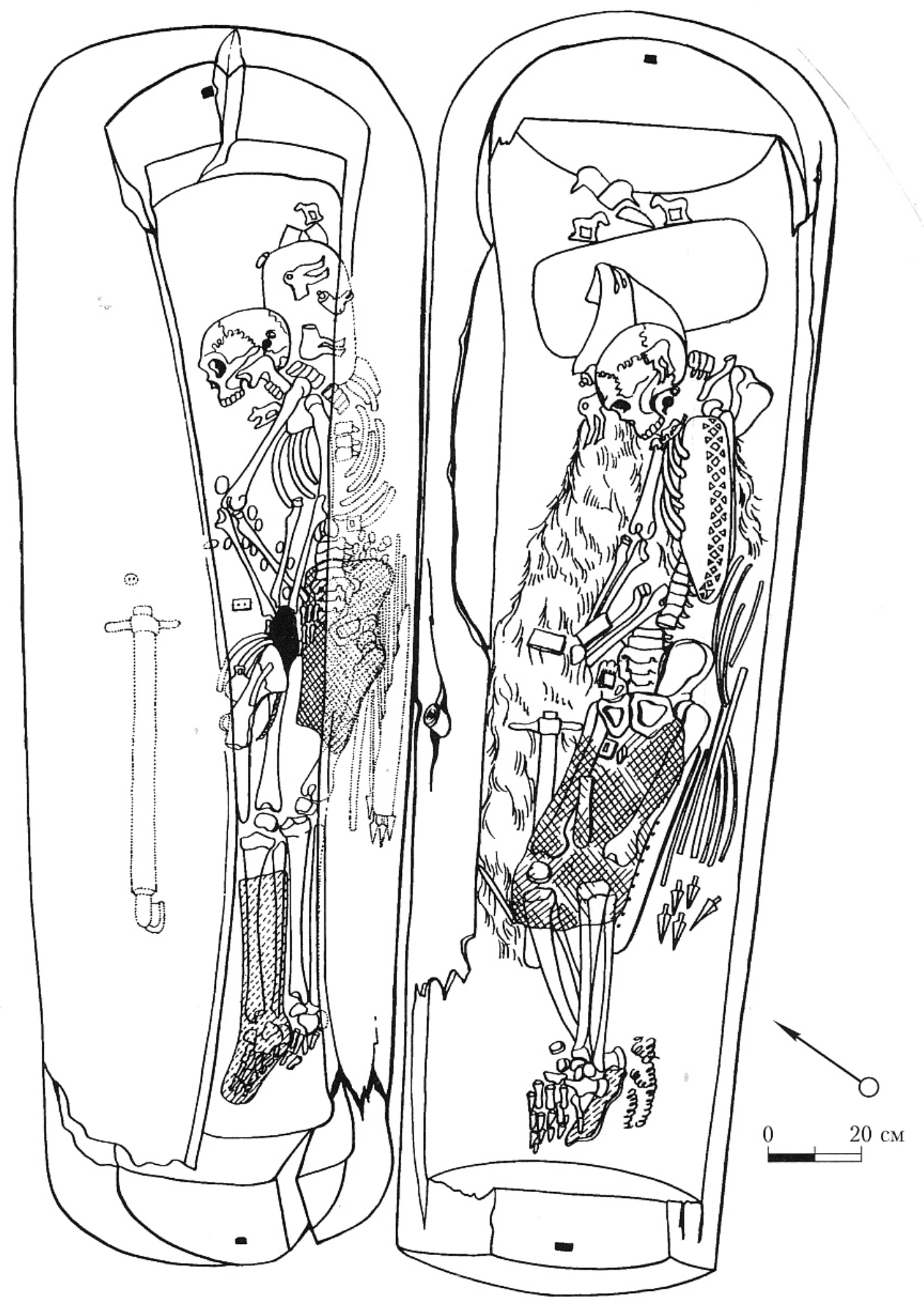

Puc. $2 a$. Расположение погребенного и предметов в элитных погребениях пазырыкской культуры: Ак-Алаха-1, курган 1, погребение 1 [Полосьмак 2001: табл. III, г]

[Fig. 2a. Layout of remains and tools in burials of Pazyryk elites: Ak-Alakha-1, kurgan 1, burial 1] 


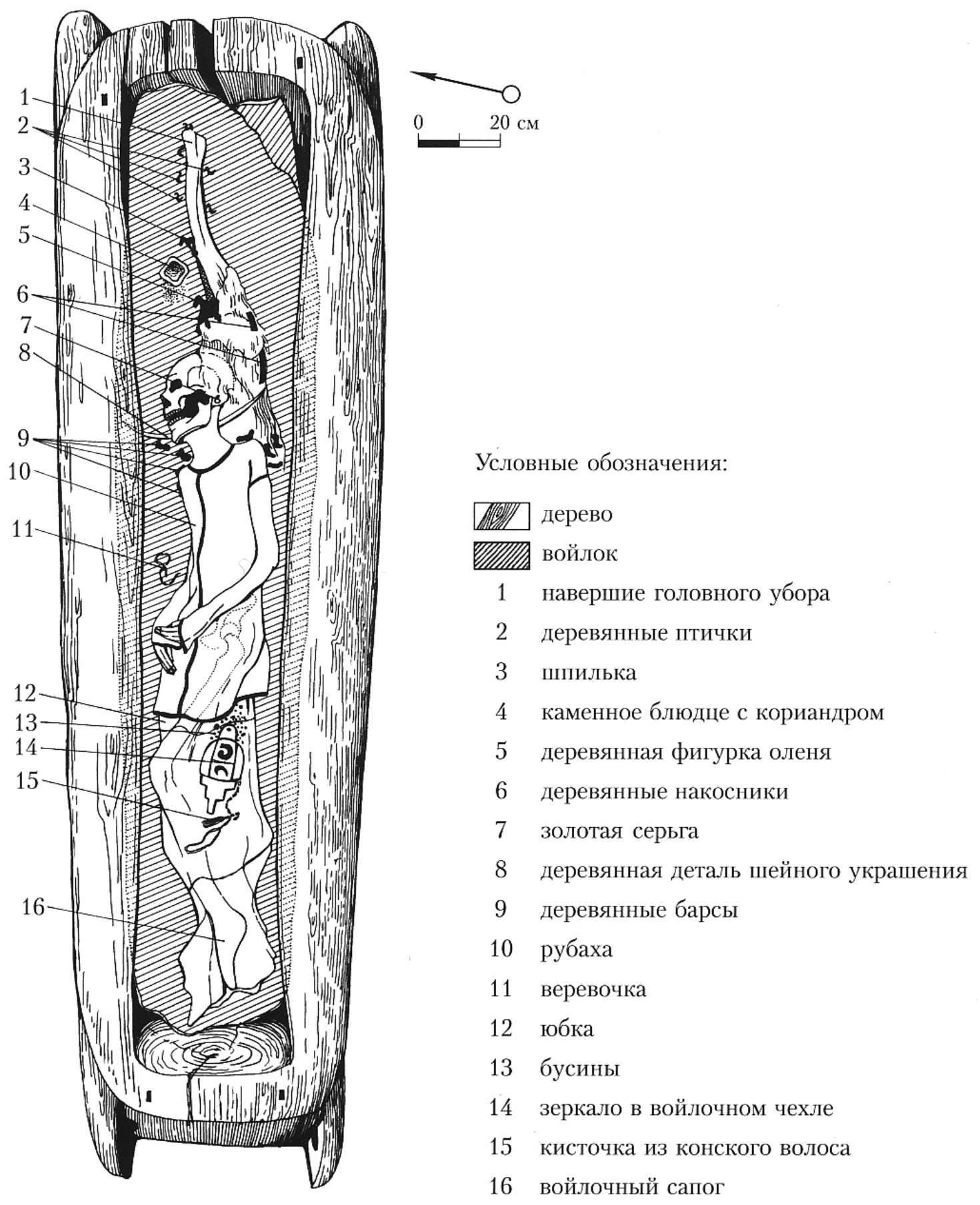

Puc. 2b. Расположение погребенного и предметов в элитных погребениях пазырыкской культуры: Ак-Алаха-3, курган 1, погребение 2 «Укокской принцессы» [Полосьмак 2001: табл. VI, б]

[Fig. 2b. Layout of remains and tools in burials of Pazyryk elites: Ak-Alakha-3, kurgan 1, burial 2 ('Princess of Ukok')] 
Поскольку в камере был только один саркофаг-колода, то по аналогии с остальными большими пазырыкскими курганами, в первом кургане, также как и во всех остальных больших пазырыкских курганах, были похоронены мужчина и женщина.

В кургане 2 Башадар в отдельных колодах были погребены, по меркам архаических обществ, престарелые мужчина (60-65 лет) и женщина (40 лет). Возрастное соответствие дает основание для предположения о семейной паре. Такое же предположение можно сделать о парном погребении в Большом Катадинском кургане, где оба погребенных были положены в вытянутом положении на столы. Однако для пазырыкцев не всегда парные погребения, даже в одной колоде, оказываются супружескими. В кургане 11 Берель, по данным генетического анализа, в одной колоде были похоронены мужчина и женщина, находившиеся в кровном родстве, возможно мать и сын [Samasev 2002: 252]. В кургане Шибе в одной колоде были похоронены пожилой мужчина 60 лет и семилетний мальчик. Специальных анализов для шибинских погребенных проведено не было, но по аналогии с берельскими, надо полагать, возможно такое же близкое кровное родство и в данном случае. Получается, в одну колоду с мужчиной, главой семьи, могли быть положены женщины (супруга, мать) и несовершеннолетние дети, то есть члены одной малой семьи.

Подросшие дети погребались в собственных колодах. В кургане 4 Пазырык были погребены два человека: мужчина и девушка 15-16 лет, каждый в своей колоде. В кургане 1 Ак-Алаха-1 были погребены: в одной колоде взрослый мужчина, в другой юноша, который был определен антропологами как девушка, но по данным генетического анализа оказался юношей [Чикишева и др. 2019].

Остальные одиночные захоронения в колоде принадлежали женщинам (Туэкma курган 2 и $A \kappa-A л а х а-3)$ и взрослым мужчинам (Кутургунтас, Туэкта курган 1, Башадар курган 1).

Важным для данного исследования является вопрос о длине колод-саркофагов. Рассмотренная ширина колоды напрямую зависела от диаметра ствола лиственницы. Поэтому дерево для колоды-саркофага выбирали подходящего диаметра, но длина ствола лиственницы диаметром 70-95 см могла достигать 20 и более метров. После того как дерево было повалено, длина ствола предоставляла широкий выбор для определения размеров колоды в длину. Исходя из этой посылки, можно предположить, что длина колоды устанавливалась только по требованиям обряда. Согласно им, длина колод пазырыкцев варьировала от 2,4 м до 5,0 м. При росте мужской части элитного пазырыкского населения в пределах 170-180 см наименьшая длина колоды в 240 см представляется более чем достаточной для размещения мумии со слегка подогнутыми ногами. Однако, как видно по таблице 1 , большинство колод достигали длины плюс-минус 3,0 м. В кургане 2 Пазырык колода достигала 4,2 м, а в кургане 5 Пазырык - даже 5,0 м. Рационально объяснить такую длину колод не получается. Это подтолкнуло С. И. Руденко к мысли о том, что мумии, возможно, лежали не рядом, а друг за другом [Руденко 1953: 50], что не подтвердилось последующими раскопками.

Исходя из общей концепции пазырыкского погребального обряда, рядовые члены общества отправлялись на тот свет в присевшем положении или опустившимися на колени, а представители элиты как бы слегка преклонившими колени, надо полагать, что на том свете первые достигали ближайший, неглубоко расположенный уровень, а последние продвигались дальше. То есть и «там» подразумевалась социальная стратификация. При этом вожди укладывались в прочные лиственничные колоды, по возможности максимально длинные, чтобы их продвижение на свой уровень был наиболее максимальным и гарантированным. Для того чтобы они случайно «не выпали» не на том уровне, колоды крепко заколачивали деревянными клиньями. Как часто трактуется в мифологии, по достижении положенного их статусу уровня клинья сами по себе должны выпасть из колоды, и умершие оказаться там, где им положено быть согласно их статусу. Символика помещения в ствол дерева также дает основание для подобной трактовки, так как дерево, как известно, соединяет все три мира. Корни его под землей, ствол на земле, а крона уже на небесах. В данном случае напрашивается сравнение лиственничных колод с лифтом, 


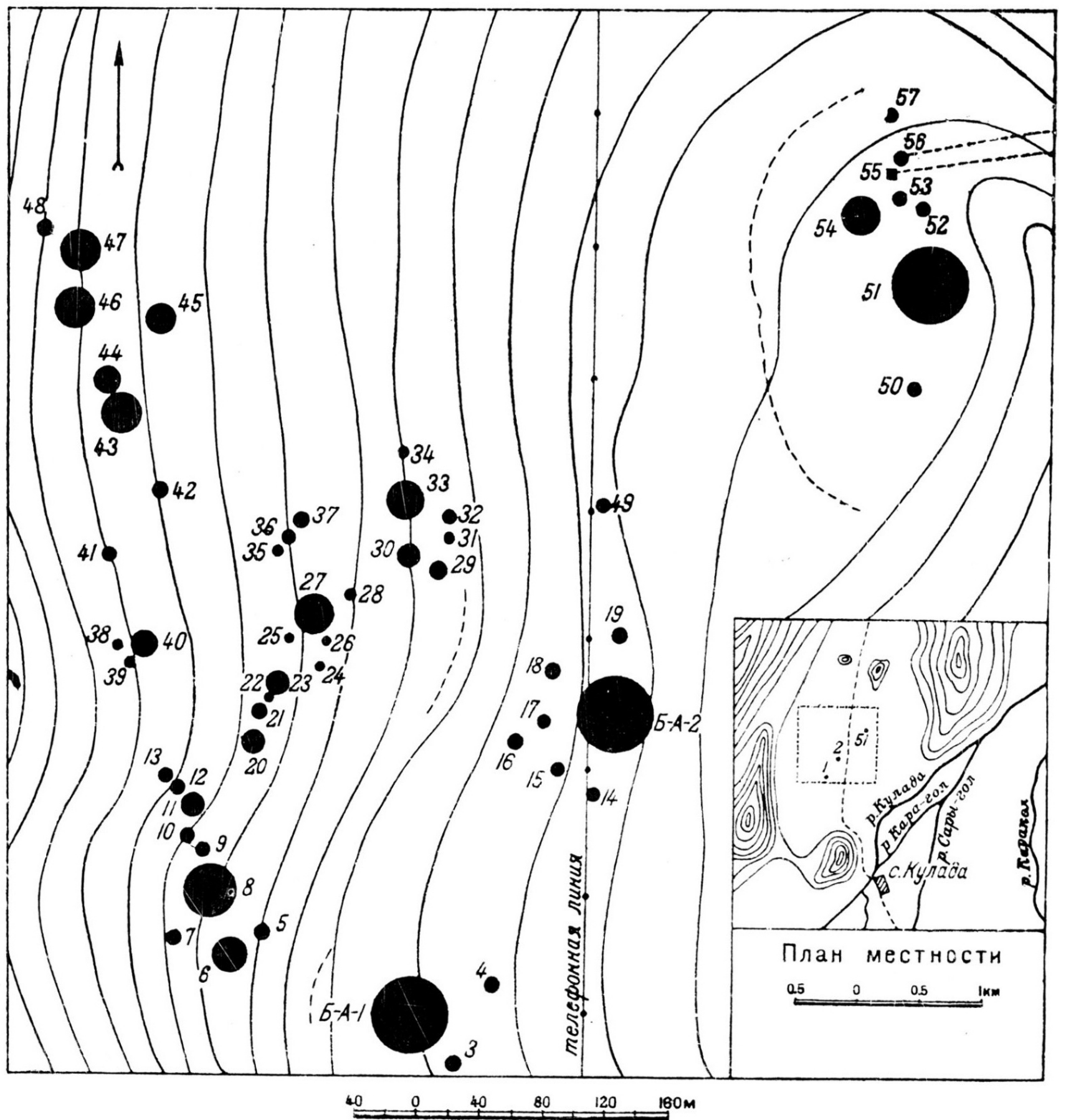

Puc. 3. План курганной группы Бамадар [Руденко 1960: рис. 10]

[Fig. 3. Plan of Bashadar kurgan group] 
доставляющем на нужный этаж. Чем длиннее колода, тем более дальних сфер достигают умершие.

Расположение умерших в колодах дает указание на направление доставки умерших. Колоды были сделаны из стволов деревьев, но голова умерших была всегда расположена в комлевой части ствола, то есть направлена к корням дерева, вниз, в подземную часть. Это предположение подтверждается таким показателем как глубина могил пазырыкцев. Чем важнее была личность умершего, тем глубже была его могила. Могилы детей всегда были не столь глубокими, как могилы взрослых. Сопровождающие конские захоронения располагались всегда выше дна могилы человека, на специальной ступеньке. Такая же закономерность прослеживается и по могилам скифов Северного Причерноморья. Сaмой глубокой могилой в царских курганах была центральная могила, за ней следовали впускные погребения, погребения слуг. Конские могилы и могилы конюхов имели наименьшую глубину [Очир-Горяева 2014а: 72, 88; Очир-Горяева 2018: 57-87]. Курганы скифов Северного Причерноморья и пазырыкской культуры обьединяет общая широтная ориентация и градация могил по глубине. В любом случае главные погребенные «ведут» за собой рядовых членов общества и младших родственников.

Аналогичный принцип прослеживается в курганах Южного Приуралья скифской эпохи, которые характеризуются противоположной ориентацией погребальных сооружений - меридиональной. В южноприуральских курганах прослеживается также противополжная градация могил по глубине, и соответственно противоположное направление - наверх. Там впускные погребения имели большую глубину, чем основное погребение этого же кургана. Оcновные погребения были расположены в широких просторных, но неглубоких ямах, либо на уровне древнего горизонта, либо на некотором возвышении - площадке из глины [Смирнов 1964; Смирнов 1975; Пшеничнюк 1983; Таиров, Боталов 1988; Яблонский и др. 1994; Яблонский и др. 1995 : 4-48; Яблонский, Мещеряков 2006]. На наш взгляд, так воплощалось представление о том, что наиболее почетные и важные персоны должны быть захоронены выше, бли- же к небу, чем рядовые. Погребенные из центральных гробниц должны были первыми достичь страны мертвых, находящейся, судя по целому комплексу данных, на северной стороне, наверху. Южно-приуральские центральные погребения были окружены кольцевым глиняным валом с разрывом с южной стороны, все впускные погребения располагались за пределами вала - полукольцом с южной стороны, то есть они как бы следовали за погребенным из центральной ямы [Очир-Горяева 2011: 344-373].

Показательно в этом плане замеченное нами расположение цепочек больших (княжеских) курганов Башадарских, Туэктинских, Берельских на восточном краю курганных полей (рис. 3).

Туэктинское курганное поле состояло из 197 курганов различных эпох [Руденко 1960: рис. 52]. У его восточного края была расположена цепочка из четырех больших курганов. Раскопаны были два кургана с северного конца, получившие название первый Туэктинский и второй Туэктинский курганы. На Башадарском могильном поле зарегистрировано несколько курганных групп из 57 курганов. Самыми восточными были три больших кургана, расположенных цепочкой с севера на юг с небольшим отклонением. Два из них, центральный и южный, были раскопаны и названы первый Башадарский и второй Башадарский курганы (рис. 3). Точно так же два наиболее крупных кургана могильника Берель были расположены несколько поодаль, на восток от основной цепи курганов, в створе друг с другом: Большой Берельский курган — на юге, на краю крутого берега р. Бухтармы, а курган 11, меньших размеров, - на севере, у самого подножия гор [Сорокин 1969: 208 236; Samasev 2002: abb. 1].

Таким образом, все большие курганы располагались с восточного края их курганных полей. При ориентации лицом на восток они оказывались «впереди» остальных. Получается, княжеские большие курганы стояли «впереди», а могилы рядовых «следовали» за ними.

Имеется еще одна деталь, подчеркивающая социальные различия между элитными и рядовыми погребениями, а именно в два раза большее количество алтарных столиков у некоторых умерших из княжеских погребений. В кургане 2 Пазырыл для погре- 
бенной пары было поставлено 4 алтарных столика, то есть по два на каждого умершего, в кургане 5 Пазырык было поставлено 3 алтарных столика с крестцом овцы и лошади также для двух погребенных. Как полагаем, двойные подношения высшим силам были предназначены для более быстрого и благополучного возрождения в лучшем мире элитных умерших по сравнению с рядовыми, имевшими по одному алтарному столику.

Выводы. Можно считать доказанным, что вытянутое и скорченное положение умерших у пазырыкцев было предписано обрядом в соответствии с социальной иерархией их общества и представлениями о потустороннем мире.

Полученный результат подтверждает и конкретизирует деление на социальные группы по размерам погребальных сооружений. Вытянутые погребения в колодах полагались для вождей племен и некоторых представителей знати.

Еще один немаловажный вопрос: всегда ли и везде ли соблюдались предписания о

\section{Литература}

Бичурин 1851 - Бичурин Н. Я. Собрание сведений о народах, обитавших в Средней Азии в древние времена. Ч. І. Отд-ние II. Ухуань. СПб.: Тип. военно-учеб. заведений, 1851. $179 \mathrm{c}$.

Бунятян 1985 - Бунятян Е. П. Методика социальных реконструкций в археологии. На материале скифских могильников IV-III вв. до н. э. Киев: Наукова думка, 1985. 416 с.

Гаврилова 1957 - Гаврилова А. А. Раскопки второго Катадинского могильника // Coветская археология. Вып. XXVII. М., 1957. C. 250-268.

Грач 1980 - Грач А. Д. Кочевники в центре Азии. М.: Наука, 1980. 256 с.

Грязнов 1950 - Грязнов М. П. Первый Пазырыкский курган. Л.: Изд-во Гос. Эрмитажа, 1950. 92 c.

Дашковский, Шершнева 2019 - Дашковский П. К., Шеринева Е. А. Новые результаты исследования кургана пазырыкского периода на могильнике Чинета-II // Полевые исследования в Верхнем Приобье, Прииртышье и на Алтае (археология, этнография, устная история и музееведение): мат-лы XIV Междунар. науч.-практ. конф. (Барнаул, 22-23 мая 2019 г.). Барнаул, 2019. С. 39-44. степени скорченности умерших. По нашим наблюдениям, предписания строго соблюдались в восточном ареале 7 пазырыкской культуры, княжеские курганы которого находились в долине Пазырык и на плато Укок, а массовые рядовые погребения раскопаны по течению р. Чуи. В западном же ареале княжеские курганы которого находились в Онгудайской долине, Канской степи и в долине р. Бухтармы, имеются рядовые погребения, в которых скорченность не столь выражена [Дашковский, Шершнева 2019]. Там намного реже встречаются сопровождающие захоронения коней, имеются также различные инокультурные отклонения, такие как диагональное расположение погребенных и т. д. Похоже, что население высокогорных долин восточного ареала оставалось более консервативным, в то время как население просторных среднегорных долин западного ареала имело в силу географической открытости больше контактов с соседними регионами, что приводило к некоторому размыванию старых местных традиций.

Кубарев 1987 - Кубарев В. Д. Курганы Уландрыка. Новосибирск: Наука, Сибирское отд., 1987. 302 с.

Кубарев 1991 - Кубарев В. Д. Курганы Юстыда. Новосибирск: Наука, 1991. 270 с.

Кубарев 1992 - Кубарев В. Д. Курганы Сайлюгема. Новосибирск: Наука, 1992. 219 с.

Кубарев, Шульга 2007 - Кубарев В. Д., Шульга П. И. Пазырыкская культура [курганы Чуи и Урсула]. Барнаул: Изд-во Барнаул. гос. ун-та, 2007. $281 \mathrm{c.}$

Очир-Горяева 2008 - Очир-Горяева М. А. Ориентация по странам света: традиции и истоки // Проблемы этногенеза и этнической культуры тюрко-монгольских народов: сб. науч. тр. Вып. 2. Элиста: Калм. гос. ун-т, 2008. C. 118-122.

Очир-Горяева 2011 - Очир-Горяева М. А. Планиграфия курганов Южного Приуралья в поздне-скифскую эпоху // Материалы и исследования по археологии Юга России. Вып. ІІІ. Ростов н/Д: Изд-во ЮНЦ РАН, 2011. C. 344-373.

${ }^{7}$ Более подробно о делении памятников пазырыкской культуры по Катунско-Чуйской гряде на западный и восточный ареалы см. [Очир-Горяева 2014б: 46-54]. 
Очир-Горяева 2012a - Очир-Горяева M. A. Древние всадники степей Евразии. М.: Таус, 2012. 486 c.

Очир-Горяева 20126 - Очир-Горяева М. A. О порядке расположения людей, инвентаря и коней в Пазырыкских курганах // Культуры степей Евразии и их взаимодействие с древними цивилизациями: мат-лы Междунар. науч. конф., посвящ. 110-летию со дня рождения выдающегося российского археолога М. П. Грязнова. Т. 2. СПб.: Периферия, 2012. C. 441-446.

Очир-Горяева 2014а - Очир-Горяева M. A. Устройство скифского кургана и его ориентация по странам света // Краткие сообщения института археологии. 2014. Вып. 3. C. $72-88$.

Очир-Горяева 20146 - Очир-Горяева М. А. О двух ареалах пазырыкской культуры Горного Алтая // Вестник археологии, антропологии и этнографии. 2014. Вып. 3 [26]. С. $46-54$.

Очир-Горяева 2015 - Очир-Горяева М. А. О возможном назначении сосудов из погребений пазырыкской культуры // Древние культуры Северного Китая, Монголии и Байкальской Сибири: мат-лы VI Междунар. науч. конф. (г. ХуХ-Хото, октябрь 2015 г.). Хух-Хото: [б. и.], 2015. Т. 1. С. 228-236.

Очир-Горяева 2018 - Очир-Горяева М. А. Планиграфия курганов как источник по семейно-родовой и социальной иерархии скифов Северного Причерноморья // Stratum plus. 2018. № 3. C. 57-87.

Полосьмак 2001 - Полосьмак Н. В. Всадники Укока. Новосибирск: ИНФОЛИО-пресс, 2001. $336 \mathrm{c}$.

Пшеничнюк 1983 - Пшеничнюк $A$. Х. Культура ранних кочевников Южного Урала. М.: Наука, 1983. 199 с.

Руденко 1953 - Руденко С. И. Культура населения Горного Алтая в скифское время. М.; Л.: AH CCCP, 1953. 401 c.

Руденко 1960 - Руденко С. И. Культура населения Центрального Алтая в скифское время. М.; Л.: АН СССР, 1960. 359 c.

Савинов 1995 - Савинов Д. Г. О ритуальном назначении погребальных камер Больших Пазырыкских курганов // Сакральное в культуpe. СПб.: ИИМК РАН, 1995. С. 6-8.

Савинов 1996 - Савинов Д. Г. Об обряде погребений больших пазырыкских курганов // Жречество и шаманизм в скифскую эпоху: мат-лы междунар. конф. (г. Санкт-Петер- бург, 12-15 марта 1996 г.). СПб.: Скифо-сибирика, 1996. С. 107-111.

Савинов 1997 - Савинов Д. Г. Погребальные камеры-«часовни» Больших Пазырыкских курганов // Сакральное в истории культуры: сб. науч. тр. СПб.: ГМИР, 1997. С. 30-40.

Смирнов 1964 - Смирнов К. Ф. Савроматы. Ранняя история и культура сарматов. М.: АН СССР, 1964. 377 c.

Смирнов 1975 - Смирнов К. Ф. Сарматы на Илеке. М.: Наука, 1975. 175 с.

Сорокин 1969 - Сорокин С. С. Большой Берельский курган [Полное издание материалов раскопок 1965 и 1959 гг.] // Культура и искусство народов Востока [Труды ГЭ. Вып. 7]. Л.: Гос. Эрмитажа, 1969. С. 208-236. Суразаков 1988 - Суразаков A. С. Горный Алтай и его северные предгорья в эпоху раннего железа. Проблемы хронологии и культурного разграничения. Горно-Алтайск: ГАНИИИЯЛ, 1988. 215 с.

Таиров, Боталов 1988 - Таиров А. Д., Боталов С. Г. Курган у с. Варна // Проблемы археологии урало-казахстанских степей. Челябинск: Челябинский гос. ун-т, 1988. С. 100-117.

Тишкин, Дашковский 2003 - Тишкин A. A., Дашковский П. К. Социальная структура и система мировоззрений населения Алтая скифской эпохи. Барнаул: Алтайский гос. ун-т, 2003. 429 с.

Чикишева и др. 2019 - Чикишева Т. А, Аристова Е. С., Елясин П. А., Полосьмак Н. В. Опухоли на костях людей из курганов пазырыкской культуры в долине реки Ак-Алахи (плоскогорье Укок, Горный Алтай) // Проблемы археологии, этнографии, антропологии Сибири и сопредельных территорий. 2019. T. XXV. C. 642-648.

Феномен... 2000 - Феномен алтайских мумий / отв. ред. В. И. Молодин, А. П. Деревянко. Новосибирск: ИАЭТ СО РАН, 2000. 320 с.

Яблонский и др. 1995 - Яблонский Л. Т., Дэвис-Кимболл Дж., Демиденко Ю. В. Раскопки курганных могильников. Покровка-I и Покровка-II в 1994 г. // Курганы левобережного Илека: сб. ст. Вып. 3. М.: ИАРАН, 1995. С. 9-48.

Яблонский, Мещеряков 2006 - Яблонский Л. Т., Мешеряков Д. В. Загадка тринадцатого Филипповского кургана // Южный Урал и сопредельные территории в скифо-сарматское время. К 70-летию А. Х. Пшеничнюка. Уфа: Гилем, 2006. С. 38-45. 
Яблонский и др. 1994 - Яблонский Л. Т., Трунаева Т. Н., Веддер Дж., Дэвис-Кимболл Дж., Егоров В. Л. Раскопки курганных могильников Покровка-I и Покровка-II в 1993 г. // Курганы левобережного Илека: сб. ст. Вып. 2. М.: ИАРАН, 1994. С. 9-54.

\section{References}

Bichurin N. Ya. Collected Data on Peoples to Have Inhabited Central Asia in Olden Times. Vol. I. Part II: The Wuhuan. St. Petersburg: Publ. House of Military Schools, 1851. 179 p. (In Russ.)

Bunyatyan E. P. Social Reconstruction Methods in Archaeology: A Case Study of Scythian Burial Sites, $4^{\text {th }}-3^{\text {rd }}$ Centuries BC. Kiev: Naukova Dumka, 1985. 416 p. (In Russ.)

Chikisheva T. A, Aristova E. S., Elyasin P. A., Polosmak N. V. Tumors on the human bones from the burial mounds of the Pazyryk culture in the Ak-Alakha River Valley (Ukok Plateau, Altai Mountains). Problems of Archaeology, Ethnography, Anthropology of Siberia and Neighboring Territories. 2019. Vol. XXV. Pp. 642-648. (In Russ.)

Dashkovsky P. K., Shershneva E. A. The new findings of kurgan of the Pazyryk period at the burial Chineta II. In: Field Studies in the Upper Ob, Irtysh, and the Altay. Archaeology, Ethnography, Oral History and Museology. Conference Proceedings (Barnaul; May 22-23, 2019). Barnaul, 2019. Pp. 39-44. (In Russ.)

Gavrilova A. A. Excavating Katada-2 burial site. Sovetskaya arkheologiya. 1957. No. XXVII. Pp. 250-268. (In Russ.)

Grach A. D. Nomads in the Center of Asia. Moscow: Nauka, 1980. 256 p. (In Russ.)

Gryaznov M. P. The First Pazyryk Kurgan. Leningrad: State Hermitage Museum, 1950. 92 p. (In Russ.)

Kubarev V. D. Kurgans of Saylyugem Mountains. Novosibirsk: Nauka, 1992. 219 p. (In Russ.)

Kubarev V. D. Kurgans of the Ulandryk River Valley. Novosibirsk: Nauka, 1987. 302 p. (In Russ.)

Kubarev V. D. Kurgans of the Yustyt River Valley. Novosibirsk: Nauka, 1991. 270 p. (In Russ.)

Kubarev V. D., Shulga P. I. Pazyryk Culture: Kurgans of the Chuya and Ursul River Valleys. Barnaul: Barnaul State University, 2007. 281 p. (In Russ.)

Molodin V. I., Derevyanko A. P. (eds.) The Phenomenon of Altaian Mummies. Novosibirsk:
Samasev 2002 - Samasev Z. S., Bazarbaeva G. A., Zumabekova $G$. S. Die «goldhütendenGreife» des Herodot und die archäologische Kultur der Früheren Nomaden im Kazachischen Altai. Skythenzeit-liche Kurgane von Berel und TarAsu // Eurasia Antiqua. 2002. Bd. 8. S. 237-277.

Institute of Anthropology and Ethnography (Sib. Branch of RAS), 2000. 320 p. (In Russ.)

Ochir-Goryaeva M. A. Ancient Horsemen of Eurasian Steppes. Moscow: Taus, 2012. 486 p. (In Russ.)

Ochir-Goryaeva M. A. Construction and geographical orientation of Scythian burial mounds. Kratkie soobshcheniya Instituta arkheologii (Brief Communication of the Institute of Archaeology). 2014. No. 3. Pp. 72-88. (In Russ.)

Ochir-Goryaeva M. A. Kurgans of the Southern Urals: planigraphy in the Late Scythian era. In: Archaeology of Southern Russia. Materials and Studies. Rostov-on-Don: Southern Scientific Center (RAS), 2011. Vol. III. Pp. 344-373. (In Russ.)

Ochir-Goryaeva M. A. Pazyryk culture of the Altai Mountains: two areas of distribution revisited. Vestnik Arheologii, Antropologii i Etnografii. 2014. No. 3 [26]. Pp. 46-54. (In Russ.)

Ochir-Goryaeva M. A. Pazyryk kurgans: positioning of human bodies, tools and horses revisited. In: Cultures of Eurasian Steppes and Their Interactions with Ancient Civilizations. Anniversary Conference Proceedings (Commemorating Prof. M. Gryaznov). St. Petersburg: Periferiya, 2012. Vol. 2. Pp. 441-446. (In Russ.)

Ochir-Goryaeva M. A. Positioning (of bodies) by cardinal directions: traditions and origins. In: Turko-Mongols. Issues of Ethnogenesis and Ethnic Culture. Collected Scholarly Papers. Elista: Kalmyk State University, 2008. Vol. 2. Pp. 118-122. (In Russ.)

Ochir-Goryaeva M. A. The social and clan relations within the Scythian society, by planigraphic analysis of the kurgans. Stratum plus. 2018. No. 3. Pp. 57-87. (In Russ.)

Ochir-Goryaeva M. A. Vessels from Pazyryk burials: potential functions revisited. In: Ancient Cultures of North China, Mongolia and Baikalia. Conference Proceedings (Hohhot; October of 2015). Hohhot, 2015. Vol. 1. Pp. 228-236. (In Russ.)

Polosmak N. V. Horsemen of Ukok Plateau. Novosibirsk: INFOLIO-Press, 2001. 336 p. (In Russ.) 
Pshenichnyuk A. Kh. Southern Urals: Culture of Early Nomads. Moscow: Nauka, 1983. 199 p. (In Russ.)

Rudenko S. I. Culture of Altay Highlanders: Scythian Era. Moscow; Leningrad: USSR Academy of Sciences, 1953. 401 p. (In Russ.)

Rudenko S. I. Culture of the Central Altay: Scythian Era. Moscow; Leningrad: USSR Academy of Sciences, 1960.359 p. (In Russ.)

Samasev Z. S., Bazarbaeva G. A., Zumabekova G. S. Die «goldhütenden Greife» des Herodot und die archäologische Kultur der Früheren Nomaden im Kazachischen Altai. Skythenzeitliche Kurgane von Berel und Tar-Asu. Eurasia Antiqua. 2002. Vol. 8. Pp. 237-277. (In Germ.)

Savinov D. G. Big Pazyryk kurgans: 'chapel-type' burial chambers. In: The Sacral in Cultural History. Collected Scholarly Papers. St. Petersburg: Museum of the History of Religion, 1997. Pp. 30-40. (In Russ.)

Savinov D. G. Big Pazyryk kurgans: burial rites revisited. In: Priesthood and Shamanism in the Scythian Era. Conference Proceedings (St. Petersburg; March 12-15, 1996). St. Petersburg: Skifo-Sibirika, 1996. Pp. 107-111. (In Russ.)

Savinov D. G. Big Pazyryk kurgans: ritual functions of burial chambers revisited. In: The Sacral in Culture. St. Petersburg: Institute for the History of Material Culture (RAS), 1995. Pp. 6-8. (In Russ.)

Smirnov K. F. Sarmatians in the Ilek River Valley. Moscow: Nauka, 1975. 175 p. (In Russ.)

Smirnov K. F. The Sauromatians: Earliest History and Culture. Moscow: USSR Academy of Sciences, 1964. 377 p. (In Russ.)

Sorokin S. S. Big Berel kurgan: complete materials of 1965 / 1959 excavations. In: Culture and Arts of Eastern Peoples. Ser.: Transactions of the State Hermitage Museum. Vol. 7. Leningrad: State Hermitage Museum, 1969. Pp. 208-236. (In Russ.)

Surazakov A. S. Altay Mountains and Their Northern Foothills in the Early Iron Age: Issues of Chronology and Cultural Classification. Gorno-Altaysk: Gorno-Altaysk Research Institute of History, Language and Literature, 1988. 215 p. (In Russ.)

Tairov A. D., Botalov S. G. Kurgan near the village of Varna. In: Ural-Kazakhstan Steppes. Issues of Archaeology. Chelyabinsk: Chelyabinsk State University, 1988. Pp. 100-117. (In Russ.)

Tishkin A. A., Dashkovsky P. K. The Scythian Altay: Social Structure and Worldview System. Barnaul: Altay State University, 2003. 429 p. (In Russ.)

Yablonsky L. T., Davis-Kimball J., Demidenko Yu. V. Kurgan burial sites of Pokrovka-I and Pokrovka-II: 1994 excavations. In: Kurgans on the Left Bank of the Ilek. Collected Articles. Moscow: Institute of Archaeology (RAS), 1995. Vol. 3. Pp. 9-48. (In Russ.)

Yablonsky L. T., Meshcheryakov D. V. Mystery of the $13^{\text {th }}$ Filippovka kurgan. In: Southern Urals and Neighboring Territories in the ScythoSarmatian Era. Ufa: Gilem, 2006. Pp. 38-45. (In Russ.)

Yablonsky L. T., Trunaeva T. N., Vedder J., Davis-Kimball J., Egorov V. L. Kurgan burial sites of Pokrovka-I and Pokrovka-II: 1993 excavations. In: Kurgans on the Left Bank of the Ilek. Collected Articles. Moscow: Institute of Archaeology (RAS), 1994. Vol. 2. Pp. 9-54. (In Russ.) 